\title{
Hand Hygiene by Healthcare Workers: a neglected practice
}

\author{
Higiene das Mãos pelos Profissionais de Saúde: uma prática negligenciada \\ La Higiene de las Manos por parte de los Trabajadores de Salud: una práctica desatendida
}

Received: 03/04/2021 | Reviewed: 03/14/2021 | Accept: 03/19/2021 | Published: 03/25/2021

\author{
Liliana Berté Fontana \\ ORCID: https://orcid.org/0000-0002-6121-696X \\ Universidade Federal de Santa Maria, Brasil \\ E-mail: lilianabfontana7@gmail.com \\ Juliana Marzari Rossato \\ ORCID: https://orcid.org/0000-0002-9310-5797 \\ Universidade Federal de Santa Maria, Brasil \\ E-mail: julianamrossato@gmail.com \\ Letícia Rodrigues Ferreira \\ ORCID: https://orcid.org/0000-0002-2366-0306 \\ Universidade Federal de Santa Maria, Brasil \\ E-mail: leticiarodfer22@gmail.com \\ Sabrina Zancan \\ ORCID: https://orcid.org/0000-0001-9219-1286 \\ Universidade Federal de Santa Maria, Brasil \\ E-mail: sabrina_zancan@yahoo.com.br \\ Ana Maria Massariol \\ ORCID: https://orcid.org/0000-0001-5407-2075 \\ Hospital de Caridade de Palmeira das Missões, Brasil \\ E-mail: enf-ana@hc.org.br \\ Terimar Ruoso Moresco \\ ORCID: https://orcid.org/0000-0002-9504-457X \\ Universidade Federal de Santa Maria, Brasil \\ E-mail: terimarm@hotmail.com
}

\begin{abstract}
Hand Hygiene $(\mathrm{HH})$ is a simple and essential action in the prevention of infectious diseases. Therefore, the aim of this study was to evaluate the levels of adherence, technique, and knowledge about HH by healthcare workers and perform an educational intervention. We conducted a cross-sectional analysis with 20 professionals, for six months. We observed and categorized the HH opportunities, evaluated the performance of the correct technique, determined the degree of HH compliance (Positivity Index proposed by Carter, IPC) and applied a questionnaire about HH. The data contributed to conduct training and discussion about COVID-19, using a didactic model of virus. We observed $\mathrm{N}=$ 791 opportunities for $\mathrm{HH}$, but only $\mathrm{N}=128(16.18 \%)$ were performed, with the correct technique in $80.47 \%(\mathrm{~N}=$ $103)$. The categories with the greatest number of opportunities for $\mathrm{HH}$ were "after patient care" $(\mathrm{N}=238)$ and "before patient care" $(\mathrm{N}=214)$. However, HH occurred only in $\mathrm{N}=76(31.93 \%)$ and $\mathrm{N}=28(13.08 \%)$, respectively. Comparing the categories, the highest adherence was "after removing the gloves" (53.19\%). The degree of $\mathrm{HH}$ compliance in this study is lower than that recommended by the IPC (70\%). In the questionnaires, workers affirmed to have taken at least one course about HH throughout their careers; few of them mentioned virus as a microbe present in the hands; "Lack of time" was the major reason to not HH. The educational intervention reinforced the importance of the correct $\mathrm{HH}$ technique, stimulated adaptations in the hospital structure and in strategies for coping with the emergence of the pandemic.
\end{abstract}

Keywords: Infectious diseases; Virus; Patient safety; Nursing; Biosecurity.

\section{Resumo}

A Higiene das Mãos (HM) é uma ação simples e essencial na prevenção de doenças infecciosas. Portanto, o objetivo deste estudo foi avaliar os níveis de adesão, técnica e conhecimento sobre HM por profissionais de saúde e realizar uma intervenção educativa. Conduzimos uma análise transversal com 20 profissionais, durante seis meses. Observamos e categorizamos as oportunidades de HM, avaliamos a realização da técnica correta, determinamos o grau de conformidade de HM (Índice de Positividade proposto por Carter, IPC) e aplicamos um questionário sobre HM. Os dados contribuíram para realização de treinamento e discussão sobre a COVID-19, utilizando um modelo didático de vírus. Observamos $\mathrm{N}=791$ oportunidades para $\mathrm{HM}$, porém apenas $\mathrm{N}=128$ (16.18\%) foram realizadas, com a técnica correta em $80,47 \%(\mathrm{~N}=103)$. As categorias com maior número de oportunidades para HM foram "após cuidado do paciente" ( $\mathrm{N}=238)$ e "antes do cuidado com paciente" ( $\mathrm{N}=214)$. No entanto, a HM ocorreu apenas em $\mathrm{N}=76(31.93 \%)$ e $\mathrm{N}=28$ (13.08\%), respectivamente. Comparando as categorias, a maior adesão foi "após retirar as 
luvas" (53,19\%) O grau de conformidade de HM neste estudo é inferior ao recomendado pelo IPC (70\%). Nos questionários, os trabalhadores afirmaram ter realizado pelo menos um curso de capacitação sobre HM ao longo da carreira; poucos citaram o vírus como um microrganismo presente nas mãos; "falta de tempo" foi o principal motivo para não realizar a HM. A intervenção educativa reforçou a importância da correta técnica de HM, estimulou adaptações na estrutura hospitalar e nas estratégias de enfrentamento à emergência da pandemia.

Palavras-chave: Doenças infecciosas; Vírus; Segurança do paciente; Enfermagem; Biossegurança.

\section{Resumen}

La Higiene de Manos (HM) es una acción simple y esencial en la prevención de enfermedades infecciosas. Por tanto, el objetivo de este estudio fue evaluar los niveles de adherencia, técnica y conocimiento sobre HM por parte de los trabajadores de la salud y realizar una intervención educativa. Realizamos un análisis transversal con 20 profesionales, durante seis meses. Observamos y categorizamos las oportunidades de HM, evaluamos el desempeño de la técnica correcta, determinamos el grado de cumplimiento de HM (Índice de Positividad propuesto por Carter, IPC) y aplicamos un cuestionario sobre HM. Los datos contribuyeron a realizar entrenamientos y debates sobre COVID-19, utilizando un modelo didáctico de virus. Observamos $\mathrm{N}=791$ oportunidades para HM, pero solo se realizaron $\mathrm{N}=$ $128(16,18 \%)$, con la técnica correcta en $80,47 \%(\mathrm{~N}=103)$. Las categorías con mayor número de oportunidades para la HM fueron "después de la atención al paciente" $(\mathrm{N}=238)$ y "antes de la atención al paciente" $(\mathrm{N}=214)$. Sin embargo, la HM ocurrió solo en $\mathrm{N}=76(31,93 \%)$ y $\mathrm{N}=28$ (13,08\%), respectivamente. Comparando las categorías, la mayor adherencia fue "después de quitarse los guantes" (53,19\%). El grado de cumplimiento de la HM en este estudio es inferior al recomendado por el IPC (70\%). En los cuestionarios, los trabajadores afirmaron haber realizado al menos un curso de formación en HM a lo largo de su carrera; pocos mencionaron el virus como un microbio presente en las manos; La "falta de tiempo" fue la razón principal para no HM. La intervención educativa reforzó la importancia de la técnica correcta de HM, estimuló adaptaciones en la estructura hospitalaria y en las estrategias para afrontar el surgimiento de la pandemia.

Palabras clave: Enfermedades infecciosas; Virus; Seguridad del paciente; Enfermería; Bioseguridad.

\section{Introduction}

Hand Hygiene $(\mathrm{HH})$ plays a central role in preventing infectious diseases at any time and in any place. The World Health Organization (WHO), with the member countries, developed the Patient Safety Program, in which six main goals were defined, focused on strategies to improve situations of greater risk to the patient (Joint Commission International [JCI], 2020). Among them, the fifth goal, which aims to "Reduce the risk of infections associated with health care", and has the HH as its main measure (JCI, 2020).

The simple practice of wash the hands was declared to decrease the microbial load and to control the spread of infectious agents, since 1847 by doctor Ignaz Philip Semmelweis (Pittet \& Boyce, 2001; Madigan, Martinko, Bender, Buckley, $\&$ Stahl, 2016). Nowadays, HH is widely practiced mainly in health services. HH includes cleaning with an alcoholic solution hand rub or with soap and water; it is preferable to rub hands with alcohol if hands are not visibly dirty; wash hands with soap and water when they are visibly dirty (World Health Organization [WHO], 2020). Also, there is a sequence of steps that correspond to the correct $\mathrm{HH}$ technique, as it reaches all parts of the hands and wrists (World Health Organization [WHO], 2009). WHO lists healthcare workers' situations in which HH is needed and describes them as opportunities. The five moments for $\mathrm{HH}$ by healthcare workers include (1) before touching a patient, (2) before performing clean or aseptic procedures, (3) after exposure or exposure risk to body fluids, (4) after touching a patient, and (5) after touching the patient surroundings (WHO, 2009). Further, other moments are important as before preparing medication, between contact with different patients, after handling materials (phone/cell phone, clipboard, sheets, pen, computer), and before and after wearing gloves (WHO, 2009).

In the current world scenario, in which the Coronavirus Infectious Disease Pandemic 2019 (COVID-19) is plaguing the planet, HH has become a protagonist. Viruses, like several bacteria and fungi, can colonize the surface layer of the skin, forming the transient microbiota (Pittet \& Boyce, 2001). Studies recommend the utilization of products that contain ethanol $70 \%$ or surfactants, like detergents and soap, which can break the cell membrane of microorganisms, causing denaturation and cell lysis (WHO, 2009). However, it seems that ethanol concentrations of $60 \%$ to $95 \%$ are deemed safe and effective for 
disinfection and use against the virus which causes COVID-19, severe acute respiratory syndrome coronavirus 2 (SARS-CoV2) (Berardi et al., 2020).

Even though they can be easily eliminated, they have a high pathogenic potential, and are responsible for most nosocomial infections (Pittet \& Boyce, 2001). Further, microorganisms can spread antimicrobial resistance as a consequence of cross-transmission (Pittet \& Boyce, 2001). Evidence shows that SARS-CoV-2, and can be transmitted from one person to another through saliva droplets (WHO, 2020). Similarly, the two other SARS-zoonotic coronaviruses CoV and MERS-CoV depict the same pattern of transmission (Riou \& Althaus, 2020). Thus, the practice of respiratory and hand etiquette, including covering the mouth when coughing or sneezing, washing hands regularly, avoiding touching eyes, nose, and mouth, is severely necessary for health services (WHO, 2020).

Healthcare workers are on the front line of this pandemic and the HH represents essential biosecurity practice. However, $\mathrm{HH}$ is a routine behavior that can often be neglected, affecting security of both professionals and patients against the virus and other hazardous agents (Chang, Xu, Rebaza, Sharma, \& Cruz, 2020). We aimed to evaluate the levels of adherence, technique, and knowledge about $\mathrm{HH}$ by healthcare workers and perform an intervention consistent with the reality found in the hospital.

\section{Methodology}

Cross-sectional study was utilized to determine the engagement in health behaviors of 20 health care professionals including nursing technicians $(\mathrm{n}=12,60 \%)$, nurses $(\mathrm{n}=6,30 \%)$ and doctors $(\mathrm{n}=2,10 \%)$, during six months (August to December 2019 and March 2020). The professionals constituted the staff of the hospitalization sector, which has the highest number of hospitalizations and people flow when compared to other sectors of the hospital, located in a municipality with 36 thousand inhabitants, at the Rio Grande do Sul State, South of Brazil. According to the hospital administration, the mean number of hospitalized patients per month was 327 in 2019. The research was approved by the Ethics and Research Committee with Human Beings of the Federal University of Santa Maria (UFSM) (No. 3.680.161/2019), according to the Resolution 466 of December 12, 2012 (CAAE: 19924619.6.0000.5346).

\subsection{Observation}

Firstly, we evaluated the moments and the techniques to $\mathrm{HH}$ based on the recommendation by WHO. The opportunities observed were divided into six different categories: (1) before preparing medication, (2) between exposure to different patients, (3) after touching any object, (4) before patient care, (5) after patient care, and (6) after removing the gloves. We observed the frequency of technique, the movements, time, and products utilized (40-60 seconds with soap and water, and 20-30 seconds with alcoholic solutions).

We counted the $\mathrm{HH}$ when the professional performed the technique outside the hospitalization rooms, which did not have a bathroom inside. We determined the degree of HH compliance using the Index of Positivity proposed by Carter (IPC) (Araújo, Simões, \& Silva, 1978). Thus, the conformity of care practice has a scale to determine the quality of the system. Desirable assistance in terms of quality should be higher than $70 \%$.

We chose a strategic point at the sector to observe, where it was possible to view all rooms and the nursing station. The research occurred in random days, shifts, and periods, totaling 45 hours of observation (from August to November 2019). We did not inform the healthcare workers about the subject of the research to avoid behavior changes.

All statistics were performed using the GraphPad Prism 6 software. Analysis of adherence to HH was compared using a binomial test to compare the observed distribution to the expected distribution. We assume the theory that an event should happen $20 \%$ of the time. Analysis of specific opportunities to HH was conducted using a chi-square test, which combines the 
discrepancies between the observed and expected values.

\subsection{Questionnaire}

After the observation phase, we applied a questionnaire composed of open and closed questions with the same healthcare workers observed (December 2019). All the participants signed the Informed Consent Form. The questions were about: HH guidelines from the Brazilian Ministry of Health; types of microbe that they believe to habit in their hands; diseases prevented with the practice of $\mathrm{HH}$; reasons that lead to practice $\mathrm{HH}$; the availability of alcohol dispensers in the sector; quality of the alcoholic solution available; among others.

\subsection{Intervention}

Data collected from observation and questionnaire phases were presented to the hospital management and Infection Control Committee (ICC) teams (March 2020). From that presentation and the emergence of COVID-19 disease in Brazil, we developed an intervention focusing on the prevention of healthcare-associated infections and COVID-19. First, we prepared an explanation about COVID-19, using a schematic model of the virus. We thought that a macroscopic structure would contribute to comprehension about viral morphology. We selected an issue about the mode of action of soap and water or alcohol to destroy the virus.

Finally, we decided to suggest the HH technique using ink mixed with alcohol gel. This activity aimed to show if the correct $\mathrm{HH}$ technique is being well developed. It consists of the application of a drop of ink mixed with alcohol gel and spread, simulating a HH. In the first step, they can observe if both hands were completely covered by color gel. In the second step, they wash their hands and visualize if they performed a good remotion of the product.

\section{Results}

\subsection{Observation}

Healthcare workers had N=791 opportunities for $\mathrm{HH}$. Assuming that the expected failure percentage was $20 \%$, we observed a significant increase in failures $(\mathrm{N}=663), 83.82 \%(\mathrm{P}<0,0001)$ (Figure 1A). From the $\mathrm{N}=128(16.18 \%)$ opportunities to $\mathrm{HH}$ successfully adhered by healthcare workers, only $\mathrm{N}=103$ (80.47\%) were correctly developed (Figure 1B). The percentage of the incorrect $\mathrm{HH}$ technique was in agreement with expected values (19.53\%, $\mathrm{P}=0.5001)$. The degree of $\mathrm{HH}$ compliance is lower than the recommended by IPC (70\%). The appropriate products to develop the correct HH technique are soap and water, an alcoholic solution, or a combination of both. From the $\mathrm{N}=128$ opportunities to HH, the percentage of specific products utilized are demonstrated in Table 1. 
Figure 1. Adherence to Hand Hygiene $(\mathrm{HH})$ by healthcare workers.
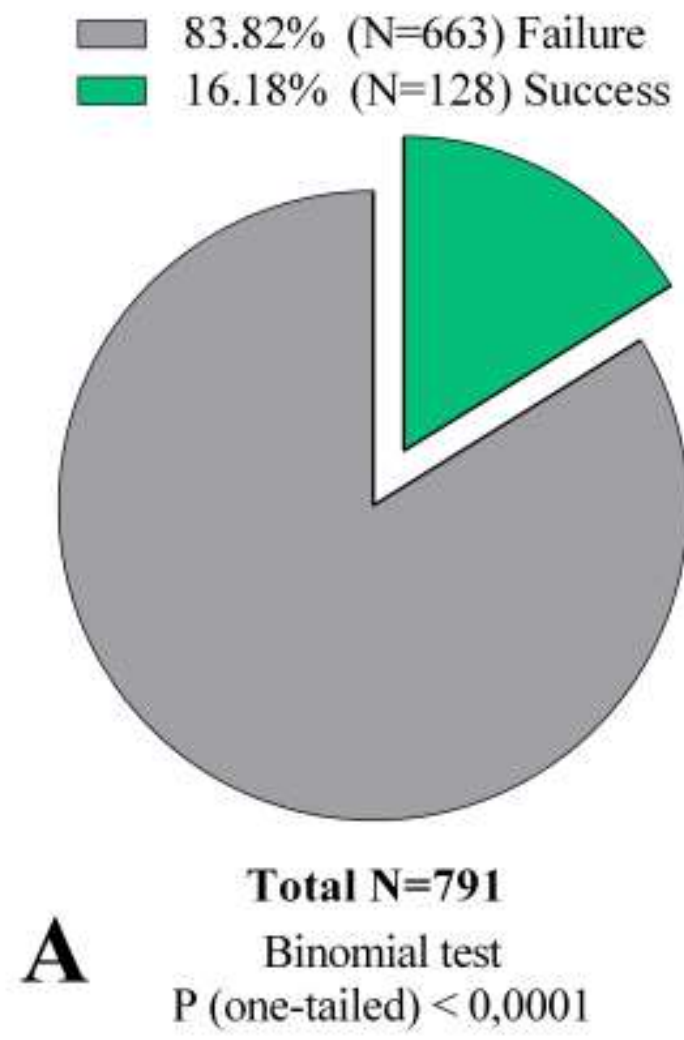

\section{$80.47 \%(\mathrm{~N}=103)$ Correct technique} $19.53 \%(\mathrm{~N}=25)$ Incorrect technique

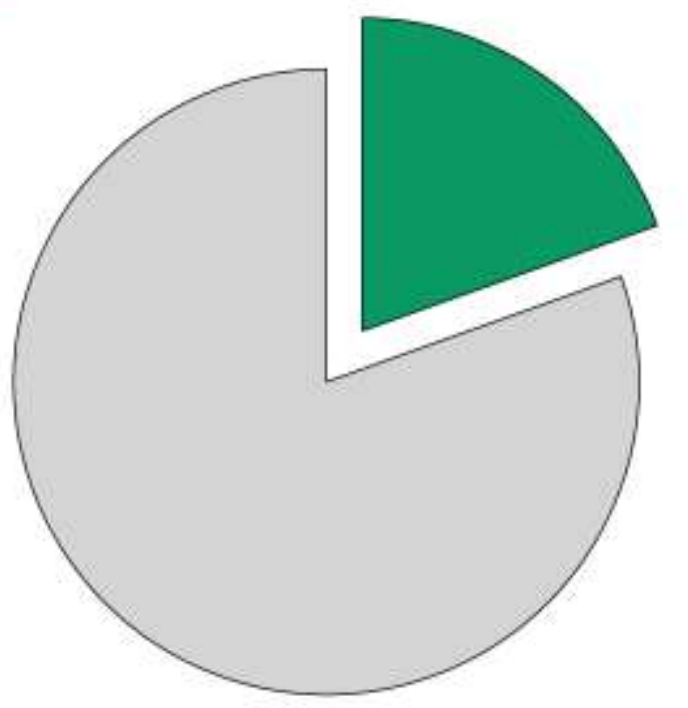

Total $\mathbf{N}=128$

B

$\mathrm{P}$ (one-tailed) 0,5001

Sources: Survey data.

The figure above shows the adherence to Hand Hygiene (HH) by healthcare workers. (A) Total opportunities to HH had a significant increase in failures $(83.82 \%)$ when compared to expected values $(20 \%)(\mathrm{P}<0.0001)$. (B) The correct HH was verified in $80.47 \%$ of successful $\mathrm{HH}$, and the incorrect technique followed the expected occurrences $(\mathrm{P}=0.5001)$. Statistical differences were determined by the Binomial test.

Table 1. Products and their frequency of use during the Hand Hygiene technique by healthcare workers.

\begin{tabular}{cc}
\hline Products utilized to HH & Frequency (\%) \\
\hline Water, soap and alcoholic preparation & $3.12 \%$ \\
\hline Water & $19.53 \%$ \\
\hline Alcoholic preparation & $21.88 \%$ \\
\hline Water and soap & $55.47 \%$ \\
\hline
\end{tabular}

Sources: Survey data.

The table above has the function of showing the different forms of $\mathrm{HH}$ performed by healthcare workers and the frequency observed in each one.

The opportunities observed ( $\mathrm{N}=791)$ were divided into six different categories described by the WHO (Figure 2). HH 
practice was low for almost all of them. The categories with the greatest number of opportunities for HH were "after patient care" $(\mathrm{N}=238)$ and "before patient care" $(\mathrm{N}=214)$. However, the HH occurred only in $\mathrm{N}=76(31.93 \%)$ and $\mathrm{N}=28$ (13.08\%), respectively.

Comparing the adherence to $\mathrm{HH}$ between the categories, "after removing the gloves" had the highest percentage (53.19\%, N=25), followed by "after patient care" (31.93\%, $\mathrm{N}=76)$, "before patient care" (13.08\%, $\mathrm{N}=28)$, "after touching any object (computer, mobile and papers)" (6.76\%, N=9), "between exposure to different patients" (5.63\%, $\mathrm{N}=4)$, and "before preparing medication" $(5.43 \%, \mathrm{~N}=5)$. Several rooms did not have a bathroom, and none of them have alcohol dispensers inside the rooms.

Figure 2. Opportunities for Hand Hygiene into categories.

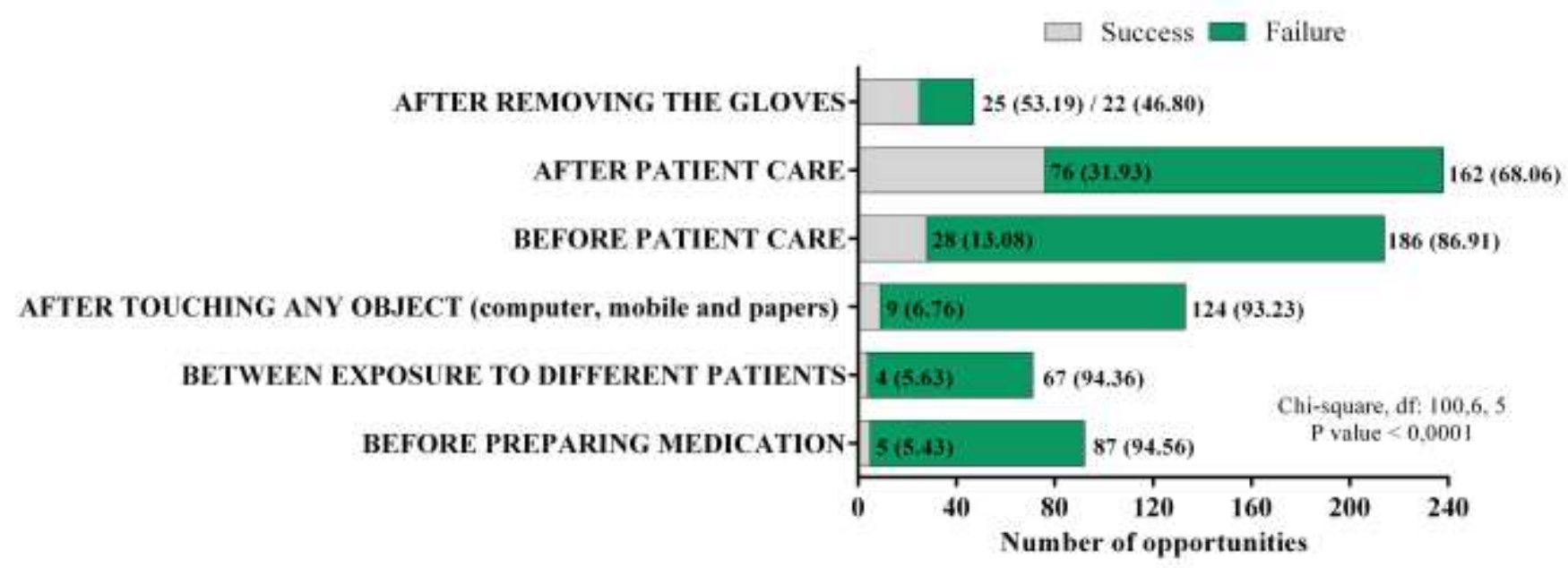

Sources: Survey data.

The figure above shows the opportunities for $\mathrm{HH}$ observed ( $\mathrm{N}=791)$ were divided into six different categories. Using the chi-square test, we found discrepancies between the observed and expected values for HH compliance of healthcare workers (Chi-square, df: 100.6, 5, and $\mathrm{P}<0,0001)$. The numbers of opportunities outside parentheses and percentages are between parentheses.

\subsection{Questionnaire}

The questionnaire was answered by $70 \%$ of the professionals observed (ten nursing technicians and four nurses). The main questions and answers are depicted in Figure 3. All of the healthcare workers reported had taken at least one training course about HH throughout their career (Figure 3A). Also, 40\% did one course and 60\% two or more. Only one professional reported not to know about the guidelines of the Brazilian Ministry of Health. When healthcare workers were asked about which microbes the hands can harbor, the majority answered "bacteria" (92.85\%). However, few participants answered, "fungi" (35.71\%) and "virus" (21.42\%) (Figure 3B). About the reasons to do HH, 71.42\% answered to "avoid crosscontamination", and $35.71 \%$ said to be a routine of behavior (Figure 3C).

Healthcare workers stated that they performed HH before assisting their patients, and $92.86 \%$ stated to know about the importance of $\mathrm{HH}$ and the correct technique. However, when participants were asked about why they did not perform $\mathrm{HH}$, the majority did not answer $(42.85 \%, \mathrm{~N}=6)$, or answered "lack of time" $(28.57 \%, \mathrm{~N}=4)$, thought it was "no dirty" $(21.42 \% \mathrm{~N}=3)$, and "lack of suitable conditions" (7.14\% 7.14\%, N=1) (Figure 3D).

About the diseases that can be avoided with the correct HH, all participants said "hospital infection". In addition, 
"respiratory disease" (50\%, N=7), "parasitic infections" (28.57\%, N=4), "chickenpox" (21.42\%, N=3), "hepatitis A" and "candidiasis" in $(14.28 \%, \mathrm{~N}=2)$ and "AIDS" $(7.14 \%, \mathrm{~N}=1)$. Regarding the alcohol gel type available at the hospital, $71.43 \%$ of workers stated that the alcohol gel has a good quality, it dries fast and does not leave hands with a slimy or sticky appearance.

Figure 3. Analysis of the questionnaires.
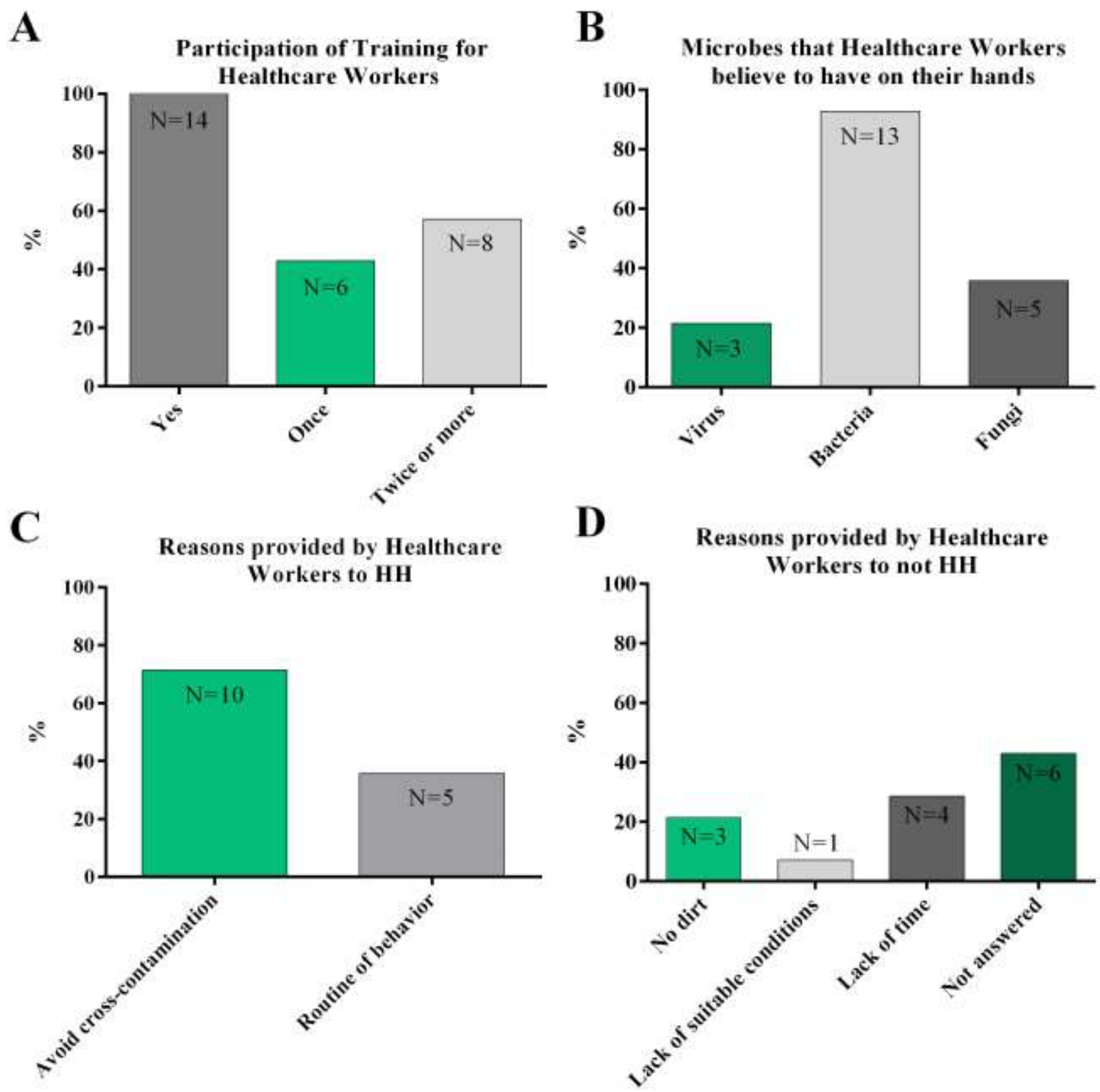

Sources: Survey data

\subsection{Intervention}

The exposition of observations and questionnaires results to the hospital management and ICC teams stimulated the development of an educational intervention with the healthcare workers. The main topics discussed were the COVID-19 pandemic disease and the correct technique of $\mathrm{HH}$. 
A virus model helped the healthcare workers to recognize the microorganism morphology, to understand the mode of action of soap and alcohol $70 \%$ to combat the virus, and the importance of following the opportunities to HH, recommended by WHO. To train the HH technique, healthcare workers used ink mixed with alcohol gel and they could observe that several areas of the hands were not well cleaned. Thus, they could realize that they did not perform the HH correctly.

Figure 4. Educational intervention activity.
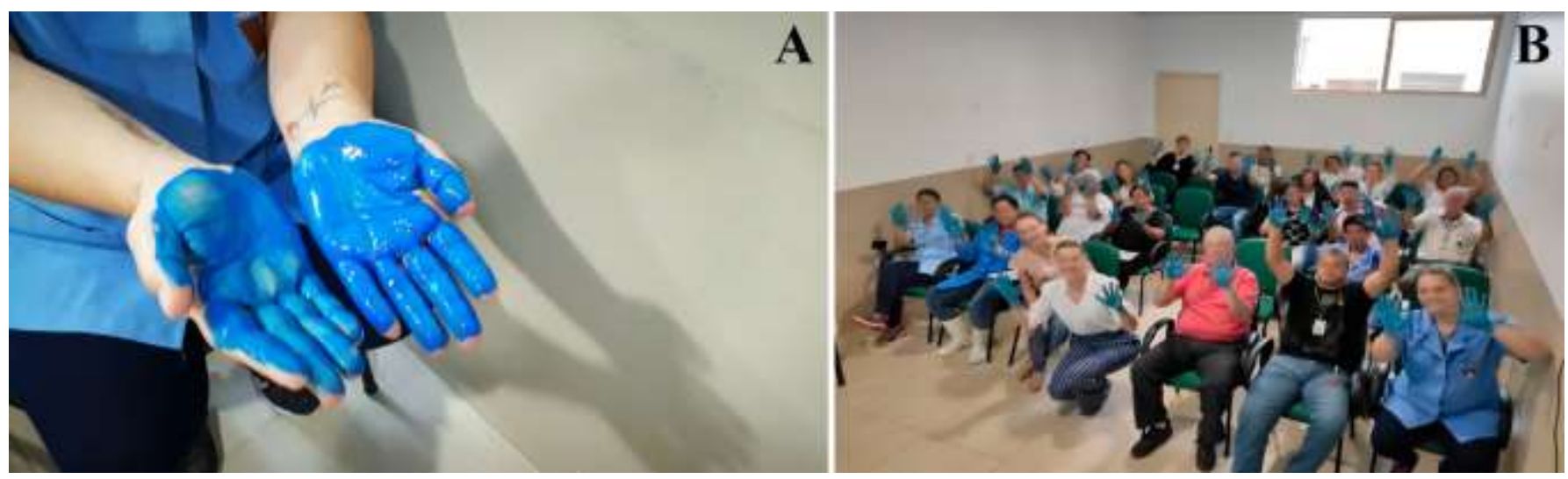

Sources: survey data.

The figure above has the function of showing the images with healthcare workers in carrying out the activity provided for in the educational intervention. (A) Hand Hygiene technique training using ink mixed with alcohol gel. (B) Group of healthcare workers that participated in activities.

\section{Discussion}

From N=791 opportunities to $\mathrm{HH}$, the successful adherence observed in this research was $16.18 \%(\mathrm{~N}=128)$. This value is lower than the recommended by IPC, to assess the quality of health services. IPC considers the rates below $70 \%$ an undesirable (Araújo et al., 1978). Similar to our results, studies evaluating the adherence to HH in hospitals from Brazil showed that the adherence rates varied between $27.7 \%$ and $67.9 \%$ (Vasconcelos, Alves, Fernandes, \& Oliveira, 2018; Santos, Roseira, Piai-Morais, \& Figueiredo, 2014; Zhang, Kong, Lamb, \& Wu, 2019; Dewes, 2019; Oliveira, de Paula, \& Gama, 2017). We assumed an expected occurrence of incorrect $\mathrm{HH}$ technique and the inappropriate use of products to $\mathrm{HH}$ were $20 \%$, and we found similar values. However, these values reflect an alarm to healthcare systems.

From the $128(16.18 \%)$ successful HH opportunities, $80.47 \%$ used the appropriate products to develop the HH technique. Soap and water or alcohol rubbing, can decrease the colonization of the transient hand microbiota (Pittet $\&$ Boyce, 2001). Healthcare workers seem to prefer the use of water and soap over an alcoholic solution, similar to observed in other studies (Santos et al., 2014; Oliveira et al., 2017). The low adherence to alcohol use may be due to the lack of alcohol dispensers in the hospitalization sector. However, $19.53 \%$ used water alone, which is not enough to inactivate microorganisms, since molecules present in the sanitizers, products based on alcohol and surfactants, act on the phospholipid bilayer of membranes (Lima, Almeida, da Fonseca, \& Gonçalves, 2020).

The greater adherence of $\mathrm{HH}$ occurred in the situations that reflect personal protection when compared to those related to patient protection, including after removing the gloves (53.19\%) and after patient care (31.93\%). Failures were too high before preparing medication (94.56\%), between exposure to different patients (94.36\%), and after touching any object (93.23\%). Similarly, other studies demonstrated greater adherence to HH after healthcare procedures than before (Pittet \& Boyce, 2001; Vasconcelos et al., 2018; Santos et al., 2014; Dewes, 2019). These results show the increased risks of exposure to 
the patients to pathogens.

As a limitation of the study, we emphasize that it was not possible to make observations inside the rooms, in the chosen hospital sector. Therefore, we were unable to assess the opportunities for HH before clean / aseptic procedures, after risk of exposure to body fluids and after touching surfaces close to the patient. These categories are present in the WHO recommendations on the five moments for $\mathrm{HH}$, however, they were not part of our protocol, which was adapted to the reality of the hospital. We chose not to evaluate inside the rooms to avoid changes in the behavior of health professionals.

From the descriptive analysis of the questions, we observed contradictory results. All the professionals affirmed to have participated in courses about $\mathrm{HH}$, however the adherence to $\mathrm{HH}$ opportunities were low and several episodes of incorrect technique were verified. Similarly, controversial results between self-evaluation and practices were already observed (Santos et al., 2014; Reilly et al., 2016). However, the results demonstrated the lack of knowledge of the guidelines on HH and training (WHO, 2009). In our case, only one professional said not know about the guidelines. A possible explanation for this result is that professionals do not recognize the moments' $\mathrm{HH}$, believing that they have adequate performance, enough level of information, or the correct frequency of HH in a work shift (Reilly et al., 2016).

Several reasons interfere with healthcare workers' decision to adhere to or not to $\mathrm{HH}$ practice. The most cited factor in this research was the lack of time. Besides, studies also describe other factors as high workloads (Zhang et al., 2019), hurry, forgetfulness, the physical structure offered by the institution, lack of example from other professionals, possible skin irritations, and lack of knowledge by professionals regarding HH (Pittet \& Boyce, 2001; Vasconcelos et al., 2018; Santos et al., 2014). In our case, the hospital physical structure also demonstrated has deficiencies.

In the hospitalization sector evaluated, there was only one washbasin, lack of bathrooms and no alcohol dispensers inside the rooms. The lack of adequate infrastructure, as straight access to sinks, with the supply of running water, liquid soap, paper towels, as well as alcoholic solutions for HH, and economic difficulties faced by the Brazilian Public Health System, compromise the quality of several care services (Massuda, Hone, Leles, de Castro, Atun, 2018). In this situation, compliance with the opportunities recommended by WHO is difficult. To improve patient safety, WHO often recommends developing strategies that promote the adherence of health professionals to the correct $\mathrm{HH}$ technique.

The presentation of results to the hospital management coincided with the beginning of positive cases of COVID-19 in Brazil. Our findings demonstrated the need for educational measures on the part of the institution to improve compliance with HH of healthcare workers. Since inadequate HH compromises patient safety, increasing the probability of cross-infection, the professionals' hands can disseminate microorganisms, including the multi-resistants, the focus of concern in hospitals (Santos et al., 2014). Thus, our results contributed to the development of measures to improve adherence by health professionals.

The first measure was the educational intervention with health professionals. We developed the activities when there were still no cases of COVID-19 in the region. Thus, professionals had time to learn about the disease, its agent, and ways of prevention. They understood that $\mathrm{HH}$ is the way to prevent viral spread, since the answers about microbes in the hands depicted that only $21.42 \%(\mathrm{~N}=3)$ cited the virus. With the correct $\mathrm{HH}$, the technique is possible to reach all parts of the hand and wrist, and the time stipulated by WHO is necessary for the action of the antimicrobial agent (WHO, 2009). The ideal technique needs to fulfill three conditions: be quick, because of the routine of health professionals, be effective in reducing contamination, and be free of side effects to the skin (Pittet \& Boyce, 2001). Further, facilitating access to HH helped to improve compliance. The participants demonstrated to be engaged in improving their care techniques.

The second measure to increase the adherence of HH by healthcare workers, the hospital managers installed alcohol dispensers in all rooms, washbasin in a strategic localization in the sector, and the installation of taps with sensors in the operating room. This adaptation facilitates adherence of the six opportunities evaluated and the 5 moments for the HH during 
patient care in the rooms, recommended by WHO. The alcohol dispensers solved the problems of lack of time for the professionals since it takes less time to HH (Pittet \& Boyce, 2001; Berardi et al., 2020).

The educational interventions with healthcare workers and structure adequacy were severely important to ensure the safety of professionals and patients to face the COVID-19 outbreak. The measures were adopted in the early stage of the pandemic when limited information about the transmission and infectious potential of the virus were available. This health institution never conducted any research on $\mathrm{HH}$ and about the importance of prevention and control of nosocomial infections.

\section{Conclusion}

In this study, the $\mathrm{HH}$ was considered neglected and insufficient to maintain a safe environment for patients and professionals. We observed inconsistency between the practice and the speech of health professionals, showing weaknesses in knowledge about the opportunities of $\mathrm{HH}$, products used, and the correct technique. Although it seems to be a simple technique, the frequency and the practice of $\mathrm{HH}$ has been a challenge. The results enabled improvements in the hospital infrastructure and served as a baseline for changing the routine behaviors of healthcare workers, showing the relevance of research. The educational intervention contributed to learning the correct technique of $\mathrm{HH}$ and to improving the health service of healthcare workers to face the pandemic of COVID-19. This research demonstrated the relevance of continuous evaluation and training in $\mathrm{HH}$ processes within the health system. The correct $\mathrm{HH}$ avoids infection diseases and is fundamental to face pandemic episodes.

\section{References}

Araujo, M. V. D., Simões, I., \& Silva, C. L. (1978). Auditoria em enfermagem. Revista Brasileira de Enfermagem, 31(4), 466-477. https://doi.org/10.1590/0034-716719780004000005

Berardi, A., Perinelli, D. R., Merchant, H. A., Bisharat, L., Basheti, I. A., Bonacucina, G., ... \& Palmieri, G. F. (2020). Hand sanitisers amid CoViD-19: A critical review of alcohol-based products on the market and formulation approaches to respond to increasing demand. International journal of pharmaceutics, 119431. https://doi.org/10.1016/j.ijpharm.2020.119431

Chang, D., Xu, H., Rebaza, A., Sharma, L., \& Cruz, C. S. D. (2020). Protecting health-care workers from subclinical coronavirus infection. The Lancet Respiratory Medicine, 8(3), e13. https://doi.org/10.1016/S2213-2600(20)30066-7

Dewes, F. (2019). Adesão à higiene de mãos em hospitais: revisão bibliográfica. Porto Alegre: LUME Repositório digital, Universidade Federal do Rio Grande do Sul. https://www.lume.ufrgs.br/handle/10183/201794

Joint Commission International. (2020). International Patient Safety Goals (IPSGs). https://www.jointcommissioninternational.org/standards/internationalpatient-safety-goals/

Lima, M. L. S. O., Almeida, R. K. S., da Fonseca, F. S. A., \& Gonçalves, C. C. S. (2020). The Chemistry Of Sanitizers In Covid-19 Times: Do You Know How It Works? Química Nova, 43(5), 668-678. https://doi.org/10.21577/0100-4042.20170552

Madigan, M. T., Martinko, J. M., Bender, K. S., Buckley, D. H. \& Stahl, D. A. (2016). Microbiologia de Brock. (14a ed.), ArtMed Editora.

Massuda, A., Hone, T., Leles, F. A. G., de Castro, M. C., \& Atun, R. (2018). The Brazilian health system at crossroads: progress, crisis and resilience. BMJ global health, 3(4). http://dx.doi.org/10.1136/bmjgh-2018-000829

Oliveira, A. C., de Paula, A. O., \& Gama, C. S. (2017). Monitoring hand hygiene: direct observation versus self-report rates. Enfermería Global, 16(4), 334343. https://doi.org/10.6018/eglobal.16.4.277861

Pittet, D. \& Boyce, J. M. (2001). Hand hygiene and patient care: pursuing the Semmelweis legacy. The Lancet Infectious Diseases, 1, 9-20. https://doi.org/10.1016/S1473-3099(09)70295-6

Reilly, J. S., Price, L., Lang, S., Robertson, C., Cheater, F., Skinner, K., \& Chow, A. (2016). A pragmatic randomized controlled trial of 6-step vs 3-step hand hygiene technique in acute hospital care in the United Kingdom. Infection control \& hospital epidemiology, 37(6), 661-666. 10.1017/ice.2016.51

Riou, J. \& Althaus, C. L. (2020). Pattern of early human-to-human transmission of Wuhan 2019 novel coronavirus (2019-nCoV), December 2019 to January 2020. Eurosurveillance. 25(4), 2000058. https://doi.org/10.2807/1560-7917.ES.2020.25.4.2000058

Santos, T. C. R., Roseira, C. E., Piai-Morais, T. H., \& Figueiredo, R. M. D. (2014). Hand hygiene in hospital environments: use of conformity indicators. Revista gaucha de enfermagem, 35(1), 70-77. https://doi.org/10.1590/1983-1447.2014.01.40930 
Research, Society and Development, v. 10, n. 3, e53510313554, 2021

(CC BY 4.0) | ISSN 2525-3409 | DOI: http://dx.doi.org/10.33448/rsd-v10i3.13554

Vasconcelos, R. O., Alves, D. C. I., Fernandes, L. M., \& de Oliveira, J. L. C. (2018). Adhesion to hand hygiene by nursing team in intensive care unit. Enfermería Global, (50), 430-445.

World Health Organization. (2020). Rational use of personal protective equipment for coronavirus disease 2019 (COVID-19). Interim guidance. https://apps.who.int/iris/bitstream/handle/10665/331215/WHO-2019-nCov-IPCPPE_use-2020.1-eng.pdf

World Health Organization. (2009). WHO guidelines on hand hygiene in health care: First Global Patient Safety Challenge Clean Care is Safer Care. https://apps. who.int/iris/bitstream/handle/10665/44102/9789241597906_eng.pdf,jsessionid=9EDBA3F541173B6A541FBEE2697DC4FA?sequence=1

Zhang, S., Kong, X., Lamb, K. V., \& Wu, Y. (2019). High nursing workload is a main associated factor of poor hand hygiene adherence in Beijing, China: An observational study. International journal of nursing practice, 25(2), e12720. https://doi.org/10.1111/ijn.12720 